\title{
Morphological changes in the proximity of the Greek colonies founded along the western (Romanian) Black Sea coast: Orgame, Histria, Tomis, and Kallatis
}

\author{
Luminița PREOTEASA ${ }^{1,2^{*}}$ \\ ${ }^{1}$ Sfântu Gheorghe Marine and Fluvial Research Station, Faculty of Geography, University of Bucharest, \\ Sf. Gheorghe, 827195, Tulcea county, Romania \\ ${ }^{2}$ GEODAR Research Center for Geomorphology, Geoarchaeology and Paleo-Environments, Faculty of \\ Geography, University of Bucharest, 1 N. Bălcescu, 010041 Bucharest, Romania
}

Received 17 November 2019; Revised 28 November 2019; Accepted 2 December 2019

*Correspondence to: Luminița PREOTEASA e-mail: preluminita@yahoo.com

\section{ABSTRACT}

This paper is a review of the up to date knowledge about the coastal environmental transformations around the Greek settlements along the present-day Romanian shoreline. The aim is to define a general pattern of the morphological configuration the Greeks were looking for when establishing their colonies. Existing quantitative and qualitative database on shoreline evolution both along the low lying deltaic sector $(\mathrm{N})$ and along the soft rock cliffs along the southern sector of the present-day Romanian coast together with the present day morphological configuration analysis at each study site were used to assess large spatial ( $180 \mathrm{~km}$ alongshore) and temporal scales (ca. $2500 \mathrm{yrs}$ ) of coastal behavior. The coastal dynamics during the late Holocene was controlled by the deltaic lobes development along the northern part of the present day Romanian coast which led to important shoreline progradation and subsequent isolation from the shoreline of Histria and Orgame Greek cities. The continuous sediment input depletion, sea level rise, storms set-up, longshore transport system and local tectonic activity drove the cliff line retreat along the southern sector, with important parts of the Tomis and Kallatis settlements being lost to the sea.

\section{KEYWORDS}

coastal evolution; sea level; ancient harbors; Greek colonization

\section{Introduction}

Black Sea (BS) was the last basin colonized by the Greeks during the $7-4^{\text {th }}$ century (c.) BC The first
Greek incursions are attested along the southern coast, which was the closest from the Aegean and Propontic (Marmara Sea) coasts where the Greeks 
found a somehow familiar landscape as in their homeland. Yet, despite the familiar newly encountered rocky cliffs morphology, the marine conditions there were far from the mild Mediterranean climate as a passage from a Greek source translated by Pomponius Mela (1: 120) informs us: "shallow, wild and nebulous, with only isolated places to anchor, surrounded by neither a gently sloping nor a sandy coastline, exposed to the north winds and, where it is not deep, stormy, undulating and surging" (Summerer L., 2015).

The first Greek colonies were founded along the southern coasts during the $7^{\text {th }}-6^{\text {th }}$ century BC with Sinope settled by Milesians (and her colonies: Kotyora, Kerasous, Trapezous), Amisos by Phokaians and/or Milesians and Herakleia by Megarians and Boiotians). At the same time, the Milesians settled also along the western coast at Histria, Appolonia, Odessos and latter, towards the $4^{\text {th }} \mathrm{c}$., merchants from Megara re-built other two sub-colonies of Byzantion and Heraklea: Messambria (Nessebar) and Kallatis (Mangalia). Further north, along Scythian coastlines, the Milesians emplaced at Olbia, Karkinitis, Tyritai and Nikonion, whereas the Megarans occupied Chersonesos. During the $6^{\text {th }} \mathrm{c}$. BC, the colonization process of the western and northwestern coasts continued with Dyonisopolis (Balchik), Olbia and Tyras at the mouths of Southern Bug and Dniester, Akkerman, Nikonion at the mouth of Lower Dnieper. Phasis, Dioskouris and Gyenos were the Greek settlements founded along the eastern coasts of the Black Sea (Avram et al., 2004). Another pole of Greek colonization during the $6^{\text {th }} \mathrm{c}$. BC was in the area of Kerch Strait and Taman Peninsula which, under the pressure of the Scythians from the northern steppe, united to form the Bosporan Kingdom in the $5^{\text {th }}$ c.: Kerch, Pantikapaion, Tyritake, Phanagora, Kepoi, Sennoi, Temriuk, Taman, Hermonassa, Golubiskaya which were also settled mainly on islands, headlands or promontories on the top of which they built the fortified cites, where they benefited from the sheltered places at the lee and at the base of the cliffs for harboring their vessels (Kelterbaum et al., 2011; Giaime et al., 2016).

Most of the colonies were emplaced on islands, headlands or promontories connected, more or less, by the mainland through low laying sandy barriers.
This seems to be a Phoenician legacy of building coastal cities as despite the rarity of such morphological feature, offshore islands placed close by the mainland seem to have represented the preferred location of the Phoenicians to settle coastal areas during the Early Bronze Age in the Mediterranean such is the case of Tyre (Marriner et al., 2008), Utica in Tunisia (Delile et al., 2015), Alexandria's Portus Mareoticus (Flaux et al., 2017), Arados and Perea in Syria, Cadix and Castillo of Doňa Blanca in Spain, Rachgoun and Siga in Algeria (Mariner et al., 2008).

Part of the ancient Greek cities founded along western and northern Black Sea are currently submerged at various degrees pointing toward major environmental coastal changes during the last almost two millennia.

Yet, no agreement exists between scientists regarding the cause of their decline, either humanrelated (invasions, disease, famine) or natural (sealevel changes, neo-tectonic movements, earthquakes, tsunamis) so that the ancient Greek colonies history and abandonment causes differ for each one. However, many of the specific sites geoarchaeological studies report natural causes as triggering the relocation of the harbor facilities and/or city abandonment. Studies dealing with geographical and environmental changes along the Black Sea coast mainly reports deltaic sedimentation and alluviation due to sea-level oscillations or sediment input fluctuations (Kelterbaum et al., 2011, 2012; Preoteasa et al., 2013; Vespremeanu-Stroe et al., 2013; Bony et al., 2015; Laermans et al., 2017, 2018, 2019; Giaime et al., 2016, 2018, Preoteasa et al., 2019) as primary causes of Late Holocene landscape changes.

Four Greek colonies have been built along the present-day Romanian coast roughly since the $7^{\text {th }} \mathrm{c}$. BC: Orgame (near Juilovca), Histria, Tomis (Constanța) and Kallatis (Mangalia) (Fig. 1). Although they remain unevenly archaeologically and geomorphologically investigated due to constraints imposed by subsequent continuous inhabitation and the building of the largest Romanian maritime ports at Constanța (Tomis) and Mangalia (Kallatis) during the last century, roughly superimposing the ancient ports, this article attempts to provide a scenario of palaeogeographical transformations at the location of each of them. This work combines the existing 
geoarchaeological information with geo-scientific data (large and medium-scales coastal dynamics data, new geophysical surveys and absolute ages) which complement the current knowledge in case of Histria and Orgame landscape changes and bring new information in the case of Tomis and Kallatis.

In the endeavor of reconstructing coastal palaeogeographic transformations a detailed analysis of the sea-level changes, large scale coastal dynamics and local configuration changes before, during and after settlements abandonment as reflected by dis- placement, re-positioning or disappearance of any major civic architectural elements such as fortification walls, roads, aqueducts, harbors, necropolis or some other sort of built areas are required. Therefore, before a review of the landscape dynamics at each study site, an assessment of the existing postglacial BS level curves are undertaken. Major Paleogeographical transformations at each study site will be discussed in terms of large scale coastal dynamics for a better understanding of the general morphodynamic context of their emplacement.

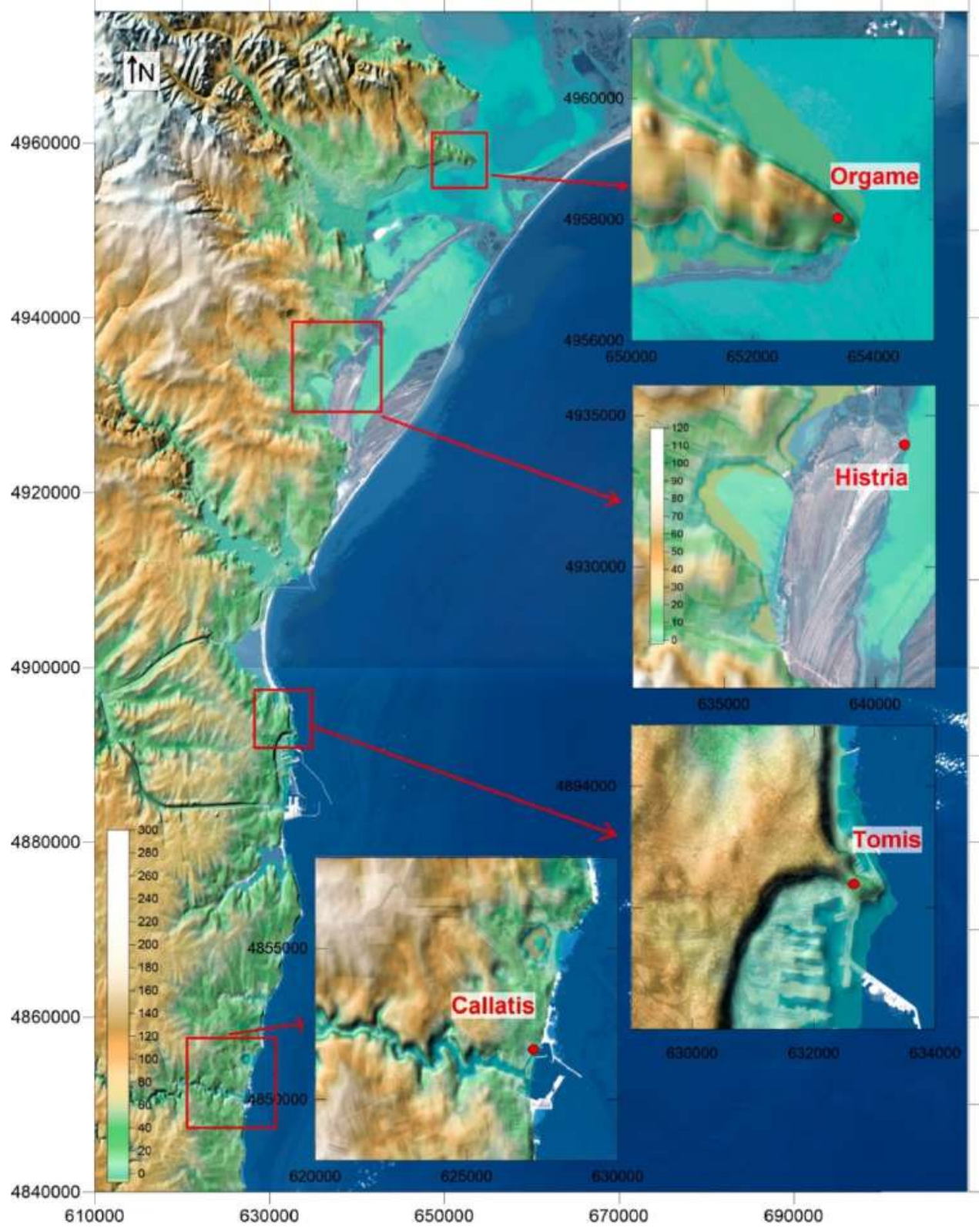

Figure 1 Black Sea Romanian coast and the position of the Greek cities: Orgame, Histria, Tomis and Kallatis 
The coastal evolution during roughly the last 2.5 millennia (spatially extending from Orgame to the north and Kallatis to the south) is reconstructed based on existing geoarchaeological data documenting major landscape transformation at each study site as well as new geo-scientific data (Electrical Resistivity Tomography profiles, absolute ages) reflecting the structure and dynamics of the coastal barriers developed downdrift of the Danube delta.

\section{Post-Glacial Black Sea level curve}

An important contribution for assessing the coastal configuration changes during the last three millennia is to establish a post-glacial eustatic BS level rise curve during mid- and late-Holocene. This topic is still ardently disputed mostly because of the sealevel proxy scarcity, uncertainty, complexity which, when assessed globally, frequently generate contrasting scenarios. Basically, two theories confront the validity of major wiggles which are presented as a peculiar post-glacial sea level rise feature for this semi-enclosed basin. Although it is expected that the eustatic sea-level curve should be similar for the Black Sea and the World Ocean after the reconnection with the Mediterranean Sea through Bosfor strait and Marmara Sea ca. 9000 ka yrs BP, some studies report or assume several wiggles associated with transgressions/regression cycles (Fedorov and Skira, 1957; Chepalyga, 1984; Balabanov, 2007; Panin and Popescu, 2007; Caraivan et al., 2012; Bolikhovskaya et al., 2018; Filipova-Marinova, 2016). These variations are generally explained either through the sensitivity of the BS as a semi-enclosed basin to regional climatic variability as reflected in palynological data (Filipova-Marinova et al., 2016; Bolikhovskaya et al., 2018) or by the drowned parts of ancient coastal settlements. At the other hand, stratigraphic investigations undertaken at various locations along the Black Sea coastlines report a gradual sea level rise trend at various rates with the present-day level as the highest during the entire post-glacial period (Bruckner et al., 2010; Kelterbaum et al., 2011, 2012; Fouache et al., 2012; Vespremeanu-Stroe et al., 2013, 2017; Laermans et al., 2018). Otherwise, these latter studies frequently report eustatic sea level is locally affected by sub- sidence associated either to sediment (peat) compaction or neo-tectonic activity (Fouache et al., 2012; Kelterbaum 2011, 2012; Preoteasa et al., 2013, 2018; Vespremeanu-Stroe et al., 2013).

Although beyond the temporal framework of the Greek colonization era, which is the subject of this paper, an illustrative example of sea-level proxies' interpretation worths being mentioned here. A recent article dealing with the multi-proxy records of the Holocene paleoenvironmental changes in Varna Lake area (Filipova-Marinova et al., 2016) reports a change in the palynological composition by the end of the Neolithic period and the beginning of the Bronze Age and interprets the 319 years long interval of absence of human related pollen spectra to the so-called Kalamitian BS transgression. Apparently, this change in vegetation composition coincides with the moment of Neolithic civilization decline. But, it is widely known among the archaeologists that the end of the flourishing Neolithic civilization in SE Europe occurred 4200-4000 BC when more than 600 tells are reported to have been burned in NE Balkans (Lazăr et al., 2012). In the aftermath of this sudden depopulation event recent studies found that new populations originating from the North Pontic Steppes (NPS) temporarily occupied the abandoned settlements, preserving the mud architecture, the house types, cult buildings (Bailey, 2000; Anthony, 2010) and cemeteries (Lazăr, 2018). Or, even if it is to admit the sensitivity of BS to climatic variations as the semi-enclosed basin, such a dramatic sea level rise to force humans to leave their settlements and to destroy those encountered in their flight from the uprising waters might be imaginable in case of a rather catastrophic event, not that of a gradual sea-level rise. It is therefore desirable to cautiously interpret the palynological data and even better to test them by confronting with results from complimentary (geochemical, paleontological) analyses, if possible.

However, the age-depth model of the sea-level proxies in the Danube delta as well from the northern and eastern BS show a continuous sea-level rise, with a recent (i.e. last two centuries) acceleration trend (Fig. 2). 


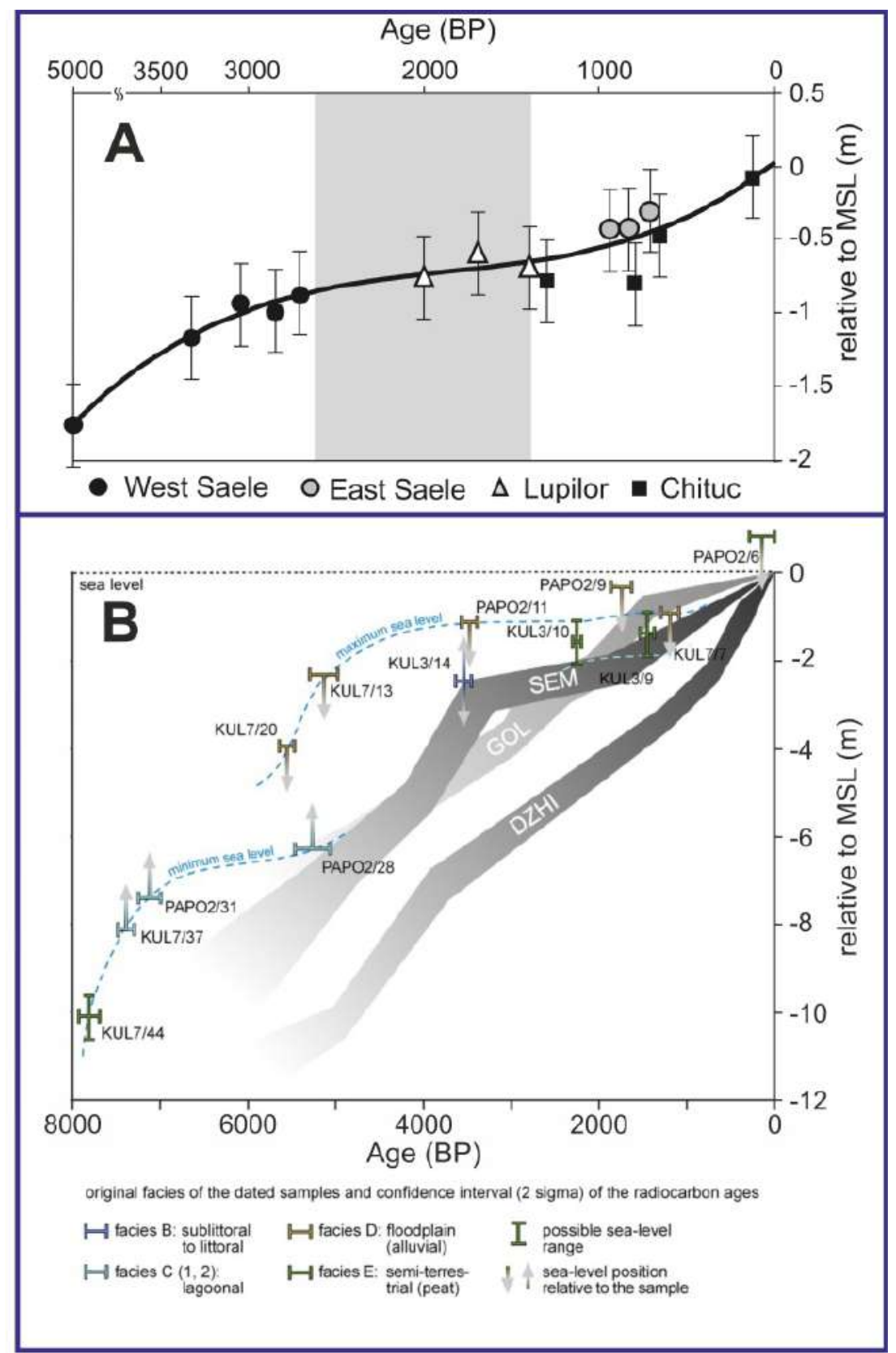

Figure 2 Sea Level A: Black Sea-level curve derived for the southern Danube Delta based on the age and altitude of the aeolian / marine deposits interface within the beach ridge plains (after Vespremeanu-Stroe et al., 2013); B: Compilation of $14 \mathrm{C}$-dated samples from the Kolkheti lowlands (eastern BS) and their relative position to the local sea level. Horizontal bar shows $14 \mathrm{C}$ dating result ( 2 sigma). The arrows pointing up/down indicate that sea level was higher/lower than the dated sample. In case of paralic peat (facies $\mathrm{E} ; \mathrm{KUL} 7 / 44, \mathrm{KUL} 3 / 10, \mathrm{KUL} 3 / 9$ ), the sea-level range was narrowed to $\pm 0.5 \mathrm{~m}$. The data set is compared to sea-level curves from the Taman Peninsula in SW Russia, with the sites of SEM $1 / 4$ Semebratnee (Brückner et al., 2010), GOL 1/4 Golobitskaya (Kelterbaum et al., 2011), and DZHI 1/4 Dschiginka (Fouache et al., 2012). The differences are due to different tectonic settings. For Kolkheti area, a continued and rather moderate rise in sea level for the last eight millennia is assumed (after Laermans et al., 2018)

Yet, no other pieces of evidence (maybe excepting the only stranded platforms from Caraharman/Vadu and Cetatea Zaporojenilor which nature is still unknown) were identified along the presentday Romanian coastline to support a past sea level higher than the present one. 


\section{Large scale coastal behavior}

The Romanian coastline consists of a $175 \mathrm{~km}$ long low lying deltaic sector to the $\mathrm{N}$ of Cape Midia and $80 \mathrm{~km}$ of soft cliffs (loess overlaying Sarmatian limestone) to the south, between Cape Midia and Vama Veche. The loess cliffs sector is generally not higher than $25 \mathrm{~m}$, at places being bordered by submerged platforms carved in limestone alternating alongshore with small pocket beaches and/or barriers closing limans. The coastal dynamics during the late Holocene generally consisted in adjustments between deltaic lobes development (i.e. initiation, extension and decay) along the northern coastal sector, and cliff line erosion under the influence of the sea level rise, storms setup, sediment input, longshore transport and local tectonic activity for the southern sector. The instrumental record of sea level at Constanța gauge between 1933 and 2000 averages $1.3 \mathrm{~mm} / \mathrm{yr}$ (Halcrow report, 2011).

The landslides which produce the cliff line retreat are controlled by both lithological and marine processes, frequently reinforced by local tectonic fault lines activity and earthquakes (Vâlsan, 1935). Tectonic movements have been reported as major controlling factors of the Black Sea basin genesis and its coastlines evolution since the first investigations of the deep sea sediments undertook by the Russian scientists starting from 1890 in the northern part of the BS basin which are thoroughly presented by Brătescu, 1944, Popescu and Ielenicz (2003), the idea of epirogenic movements contribution to shoreline dynamics over that of eustatic changes being also propagated and reinforced with new evidence by Fouache et al., (2012), Bruckner et al., (2010), Keltebaum et al., (2011). The hydrogeological characteristics of the limestone bedrock promotes a more vigorous endorheic system fed mainly by meteoric waters (Capotă, 1980, Rădoi, 1986) which favor intensive karstic processes affecting the limestone bedrock. This is reflected by the large caves (e.g. Limanu Cave) dolines, karstic depressions (e.g. Obanu Mare or present-day Herghelia Lake situated to the NW and $\mathrm{N}$ of Mangalia formed within former karstic depression) or encased valleys (e.g. Limanu, Tatlageac, Techirghiol) developed across the South Dobrudja Plateau. Large subsidence processes which reach the highest rates in Dobrudja along the coastal strip where they amount to $3 \mathrm{~mm} / \mathrm{yr}$ were documented by Dumitriu, 2012; Rădulescu et al., 2016. A survey across the submerged limestone platform at Agigea, south of Constanța Port intercepted numerous doline-like features on platforms lying at various depths which might result from limestone dissolution and marine erosion (see further, section 5).

Cliffs lithology and stratigraphy (quasi horizontal layers of loess and palaeosoils overlying limestone) favors frequent landslides triggered by both direct waves attack along the exposed loess sectors where the bordering submerged limestone platform is either missing or lies at greater depths or by subsurface seepage which is more intense in the proximity of the irrigated agricultural or inhabited areas (e.g. Tuzla, Costinești). Before the anthropogenic interventions especially from the '60s (Constanța port dykes and jetties, breakwaters) the spatial limit of the deltaic development influence on the downdrift coastline depended on the position of the active Danube's distributary, sediment volumes transported by the longshore currents system, coastline orientation and the seaward limit of the main natural headlands. However, the young ages of the southern part of Chituc beach-ridge plain, of ca. 200-130 yrs BP (Vespremeanu-Stroe et al., 2017) suggest that the last phase when Danubian sands reached and directly contributed to the sub-aerial beaches of the southern Romanian coast occurred recently and was spatially constrained mainly $\mathrm{N}$ of Constanța (Cape Singol). This fact is further endorsed by shoreline dynamics computed for the quasi-natural regime of the last century (19001960) which shows moderate shoreline progradation rate north of Cape Midia, amounting to $\sim 2$ $\mathrm{m} / \mathrm{yr}$ and slowing down to $\sim 1 \mathrm{~m} / \mathrm{yr}$ along the downdrift Mamaia barrier (Constantinescu and Giosan, 2017) which acted as the last sediment trap of the Danubian sediments.

The shoreline dynamics computed for the southern part of the Romanian coastline during the last century (Constantinescu and Giosan, 2017) show averages rates ranging from $-0.3 \mathrm{~m} / \mathrm{yr}$ for the cliff sector between Cape Aurora and Mangalia Port to +2.5 m/yr between Cape Midia to Cape Gârgâlac. The overall shoreline dynamics trend during the last 
century is slightly prograding updrift of Constanța Port, averaging $+1.15 \mathrm{~m} / \mathrm{yr}$ while slightly erosive along the downdrift sector from Constanța to Vama Veche with an average retreating shoreline rate of $0.19 \mathrm{~m} / \mathrm{yr}$. However, these rates should not be considered as representative for the last two and half millennia as the sediment accumulation along the northern sector is a recent process occurring during the last centuries which was greatly amplified by the formation and abandonment of the deltaic lobes (Dunavăț lobes, Vespremeanu-Stroe et al., 2017) and later by the emplacement of Midia and Constanța port jetties which were constructed perpendicular to the prevalent southward directed longshore transport, capturing thus most of the sediments or due to the fact that the computations were made for a time interval when the sea level rise trend was significantly accelerated since the postindustrial era (IPCC, 2002).

\section{Ancient harbors}

Harbors structures or at least shoreline configuration proper for harboring large maritime vessels are indisputable components of the coastal Greek cities territory. The intense commercial ties with other Greek colonies around the BS and Mediterranean (e.g. Khios, Lesbos, Thasos) is reflected by material exchanges documented by the numerous archaeological findings, especially pottery, allochthonous raw materials, literary, numismatic and epigraphic sources. Despite the numerous indices of ports presence, no mention exists about their emplacement. Their much hidden present-day status rendered them significant target for the geoarchaeological studies. They are now considered important proxy in deciphering the environmental changes as they account for sea level at the time of their building, shoreline position or site accessibility from the sea as well as post-abandonment environmental history. Therefore, most of the geoarchaeological studies aim at finding the location of the ancient ports in order to assess the environmental changes (Hochmann, 1997, 1998, 1999 cited in Alexandrescu, 2001, Scopan, 1973, Dăbâca, 2012, 2013, Bony et al., 2015, Angelescu, 2018).

Due to their post-colonial inhabitation and preservation degree Orgame, Histria, Tomis and
Kallatis enabled a various degree of archaeological survey of which only Histria and Orgame benefited from the lack of subsequent inhabitation after the roman-byzantine limes decline in the $7^{\text {th }} \mathrm{c}$. AD (Histria) and $11^{\text {th }} \mathrm{C}$. AD (Orgame) at one hand and more than a century of systematic archaeological investigations (at Histria) on the other hand.

\section{Histria}

Histria's Greek city ruins currently lie at $8 \mathrm{~km}$ inland from the modern shoreline. The way the natural landscape evolved since the first Greeks arrival (657 c. BC) was one of the first objectives of the archaeological research program at Histria and Orgame. The first hypothesis of the way the Histrian acropolis was related to the mainland was formulated by Pârvan in 1914. Archaeological excavations, geophysical investigations, aerial photographs interpretation and absolute datings gradually contributed to sketch a general picture of the local palaeogeographical transformations. A substantial contribution to understanding the palaeogeographical changes at Histria was brought by the aerial photographs taken by Ştefan (1974) which enabled the visualization of major discontinuities in the ancient roads connecting Histria with settlements from its rural territory. Examples of such a dramatic change documented by the aerial photographs are the western and northern roads which fade beneath the waters of Histria and Nuntași Lakes and under the present-day marshy area with reeds bordering the northern part of the acropolis. Additionally, pieces of aqueducts supplying water to Histria from Fântânele (NW) were found stranded within the northern loess bank and in the Histria Lake waters. Not only the roads and aqueducts but also tumuli, domestic buildings and segments from the roman defense wall extending about $64 \mathrm{~m} \mathrm{~N}$ have been reported as drowned within Histria Lake and the marshy area $\mathrm{N}$ of the acropolis (Dumitriu, 1966; Alexandrescu, 2002) Moreover, the quest for identifying the position of the harbor(s) of such a great city as documented by the intensive commercial exchanges with cities from the BS basin and the western Mediterranean, as well as by the marble anchors found on site lead to major findings indicating substantial local topographical changes since 
the Greek settlers emplacement. Synthesis of the so far documented landscape changes and their interpretation were previously published: Hanganu, 2012, Vespremeanu-Stroe et al., 2013. One of the most significant reports about the ancient Histrian topography (Alexandrescu, 2002) discusses the presence of several important elements in deciphering local morphological changes found into the Sinoe Lake waters and the marshy area from the north of the acropolis, as well as the basin (the present-day area called "Sărătura (the pond)") situated eastward of the late roman wall and investigated by geoelectrical, geophysical and bathymetrical surveys by a German team from Erlangen University lead by Olaf Hockmann and Chr. Borker during the '90s. The structure reported by the locals as "the road" and thoroughly investigated (Höckman et al., 1998, 1999) lies at about $1 \mathrm{~m}$ beneath the Sinoe Lake water surface, at about $70 \mathrm{~m}$ seaward of the presentday easternmost green schist outcrop of the acropolis and about $200 \mathrm{~m}$ NNE from the sacred zone of man-made dyke-like structure made up of two parallel walls widening northward which function is still controversial (e.g. archaic defensive wall, harbor structure). This structure might have had served as an artificial channel whether or not used for small boats navigation or perhaps is part of the Hellenistic fortification wall before their collapse into the water, but the debate continues as no information about the distance between the two parallel walls exist.

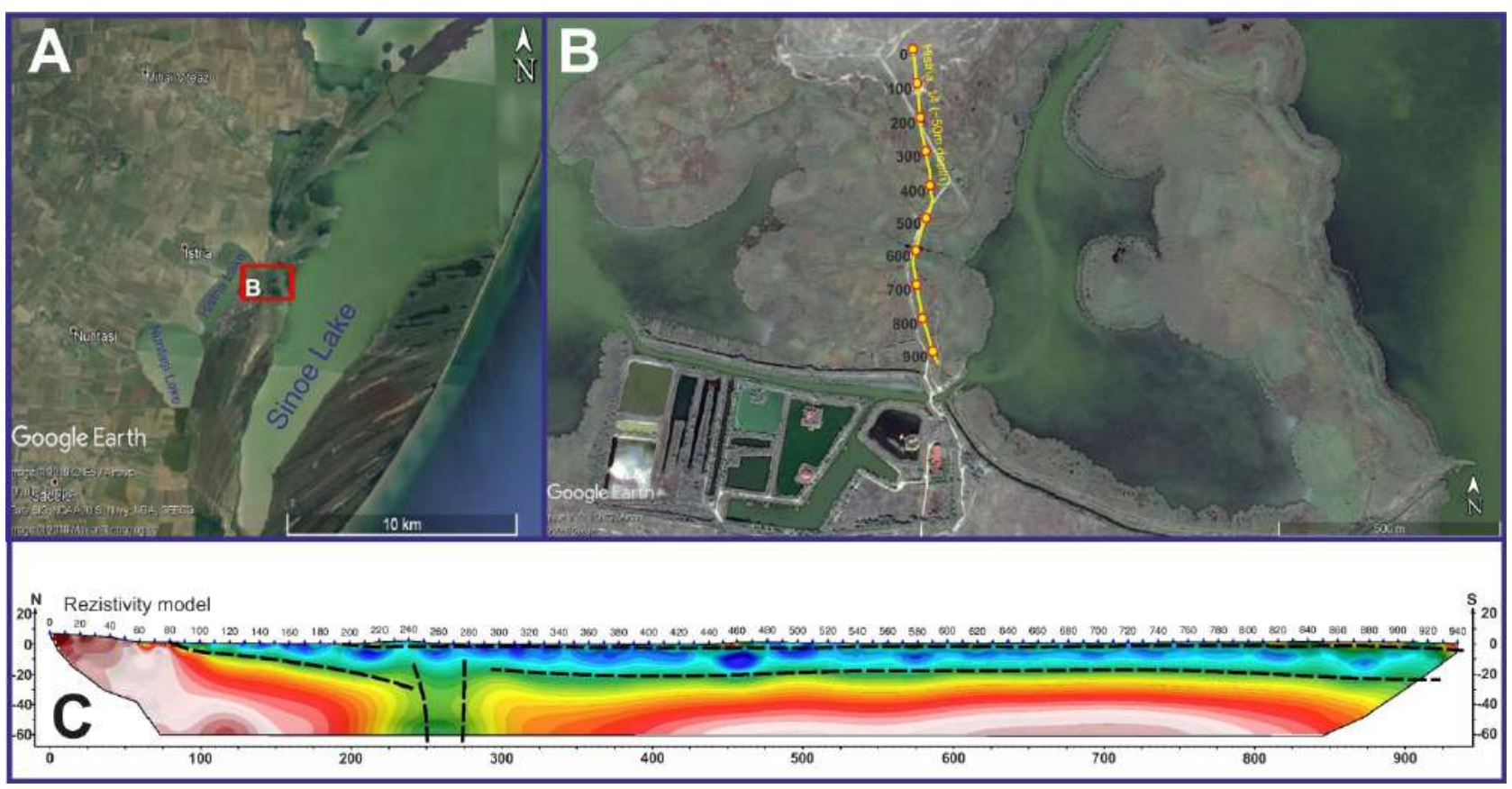

Figure $3 \mathrm{~A} \& \mathrm{~B}$ Position of the Electrical Resistivity profile running N-S across the isthmus at the NW Histria acropolis; $\mathrm{C}$. $60 \mathrm{~m}$ deep ERT profile intercepting a discontinuity within the greenschist fundament which might correlate with those intercepted further eastward by surveys reported by Hochmann et al., 1997,1998,1999 cited by Alexandrescu, 2001)

Another intriguing element reported in this paper is represented by the rectilinear WNW-SSE-E ditches found within the marshy flat to the north of Saele beach ridge plain (henceforth b.r.p.) and the acropolis and which is paralleled by other three smaller ridges. Given their spatial relationship with the artificial structure which is supposed to have been part of the Roman defense system (Alexandrescu, 2002), a recent (2016) $60 \mathrm{~m}$ deep Electrical Resistivity Tomography (ERT) profile, N-S orientated across the isthmus situated $\mathrm{N}$ of the acropolis, revealed the presence of several profound disruptions extending down within the greenschist as W-E aligned (paleo)-valley (i.e. ancient Duingi or Istria river) or fault lines (Fig. 3). The sedimentary layers overlying the fundament shows a loosely folded structure which might reflect a mechanical tension probably related to an earthquake. Otherwise, earthquakes are frequently reported in ancient sources within the whole BS basin (Bony et al., 
2012), a synthesis of those affecting Histria during the antiquity being published by Florescu, 2001. Ancient sources (i.e. Strabo, Polybe) report Histria's port clogging by the year 260 BCE by sandbars formation which impeded maritime navigation starting from the second half of the $3^{\text {rd }}$ c. BCE (Bounegru, 2003) and which probably imposed city's port relocation somewhere southward (Dăbâca, 2012).

\section{Orgame}

Orgame was founded during the $7^{\text {th }} \mathrm{C}$. BC on the narrow, asymmetric sloping Doloșman Cape made up of limestone, which separates Razelm Lake to the north from Golovita Lake to the south. The northern slope of the cape is rectilinear, steep, W-E orientated while the southern slope is more gentle, providing a milder climate on the sunny and sheltered slope. This configuration readily suggests the position of the former harbor being emplaced at the southern slope foot in present-day Golovița Lake.

An important contribution to understanding Late-Holocene landscape evolution at Orgame was brought by the geo-scientific data published by Bony et al., 2005. Basically, the textural analyses and statistical interpretation of microfauna (ostracodes and forams) species found at different depths, together with radiocarbon ages lead to the differentiation of four main ecological contexts: marine bay, oligo to mesohaline infralittoral semi-closed lagoon, coastal oligohaline lagoon under fluvial influence, wetland populated with phragmites. The context of the identified ecological changes are ascribed to successive seaward development of different coastal barriers: the first, which partially closed the shallow marine bay formed 5200-3500 cal yrs BP resulting in present-day Zmeica Lake, corresponds to presentday Zmeica barrier, the second, Lupilor barrier, formed seaward and downdrift during 3500-2000 cal yrs BP interval generating Golovița Lake, while the latest, Chituc, started to form ca. 1200 yrs BP separating Sinoe Lake from the sea.

Yet, a different evolutionary scenario stems from the palaeogeographic information contained so far in the cores published in Vespremeanu-Stroe et al., 2017 paper with most of the barriers being a remnant of ancient deltaic lobes (i.e Zmeica ridges as remnants of the barrier-marsh plain developed downdrift of Sf. Gheorghe I lobe, Lupilor b.r.p as part of the Dunavăț lobe and Young Saele (eastward of C-ridge contact unit: see Preoteasa et al., 2013) and Chituc as b.r.p developed as continuous shoreline progradation following updrift Dunavăț lobe erosion), while the evolution of the lakes being mainly forced by tectonic and deltaic sediments compaction related subsidence.

\section{Tomis}

Tomis was set as a Milesian colony on the tomitan promontory during the $6^{\text {th }}$ century which served as an important navigation hub along the western BS coast (Vulpe, 1969; Rădulescu and Scorpan, 1974) and, most probably declined during the $7^{\text {th }}$ century CE (Rădulescu, 1966). It benefited from the highly indented embayment south of the peninsula which served as shelter for the city's harbor.

Despite the ruins found at the SE base of Tomis Peninsula facing the city' $s$ port no systematic research have been undertaken to establish the extension of the built structure, most of them being destroyed at the construction of the modern port. Constanța's shoreline is basically dominated by the Sarmatian limestone platform made up of quasihorizontal layers with different roughness, rising up locally to $5 \mathrm{~m}$ above the sea level. Bathymetric surveys along Agigea shoreline sector, south of the present day Constanța Port intercepted three steps of the Sarmatian limestone platforms laying at different depths $(-1.5 \ldots-3 m ;-6 \ldots-8.5 m ;-9 \ldots-11 m)$. Each limestone step shows obvious features of combined chemical dissolution and mechanical activity (Fig. 4). The platforms on the profile in Figure 4 reflect differential erosion of limestone layers and show the submerged morphological configuration in the proximity of the Constanța seafront.

\section{Kallatis}

If disregarding the confusing and imprecise literary sources (i.e. Ps. Skymnos which mention the city's foundation at 761-764) and taking into account the material findings in archaeological excavation at Kallatis and within its rural territory (chora) the Doric colony of Kallatis was founded together with its territory during the $4^{\text {th }}$ century $\mathrm{BC}$ by Herakleia Pontica. Considering the extension of its rural territory and 
its fortification (e.g. Albeşti) and the large volume of grains trade documented as the main exported merchandise it seems that agricultural practices were the main source of its outcome. The large commercial activities should have been supported by extensive navigation. The underwater archaeological investigations were undertaken during the '70s (V. Cosma, 1973; C. Scarlat, 1973, 1976) in front of the modern city waterfront revealed the presence of submerged structures which were interpreted as port structures (Bounegru, 2002). During the under- water surveys undertaken during the last century, the supposed harbor extension was established to the $\mathrm{N}$ up to the Hellenistic and Roman fortification wall which was found to extend seaward through a shore perpendicular dyke which turns $S$ up to the entrance into the Mangalia Lake. This structure was interpreted as the siege of the military port. In front of the modern Limanu lake entrance a $1600 \mathrm{~m}$ long, shore parallel mole with storage spaces was identified made up of limestone sledge.
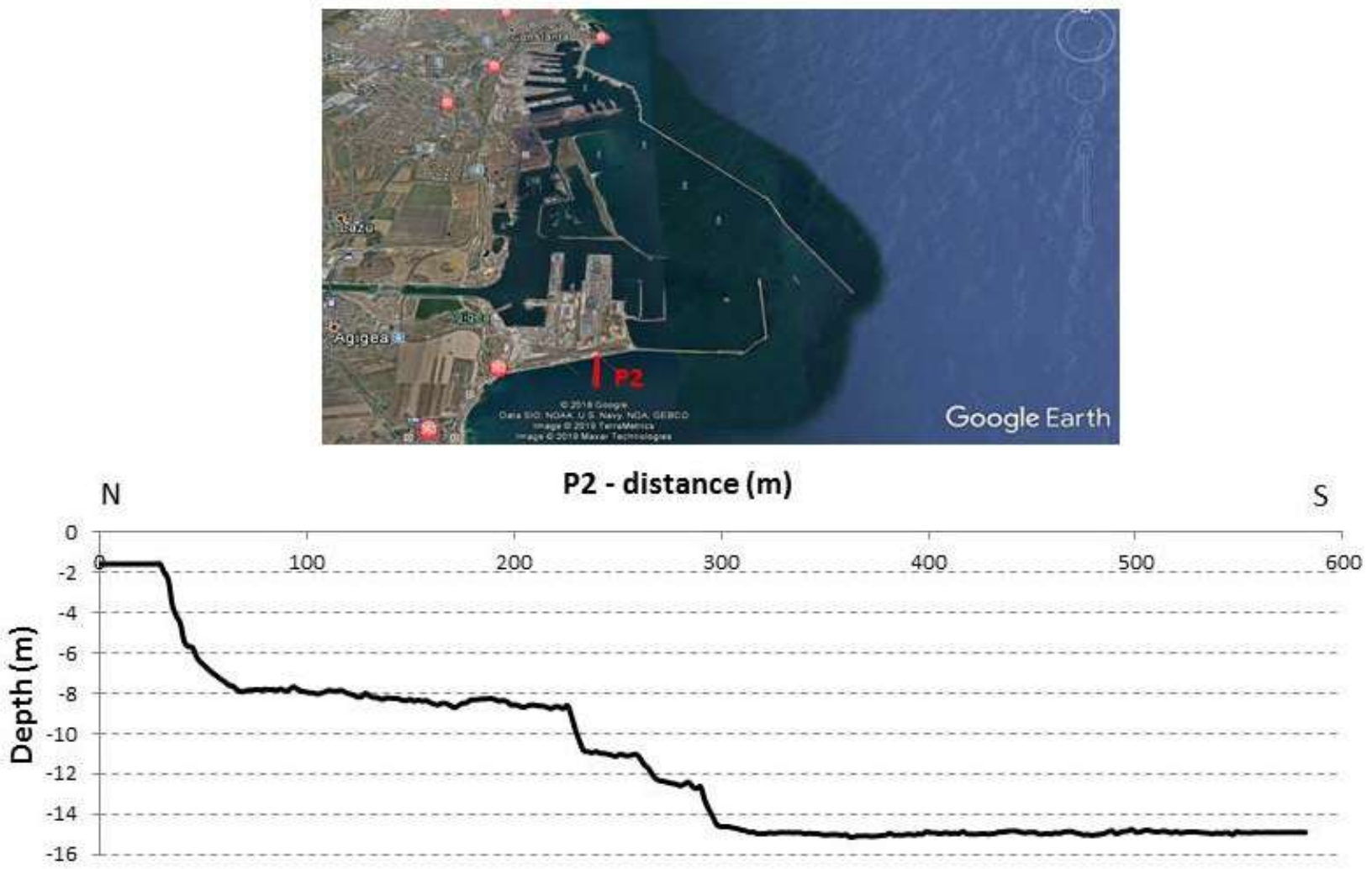

Figure 4 Upper panel: Google Earth image showing the location of the N-S orientated bathymetric profile; Lower panel: profile intercepting the limestone platforms at various depths on which circular depressions were sculpted in association with dissolution and mechanical processes

Recent bathymetric surveys confirmed the extension of a dyke in the proximity of the modern Mangalia Port southern dyke at 2 Mai. Similar findings along the banks of Limanu Lake was supposed to be large storage and mooring facilities which together with the submerged structures found in front of the city were supposed to reflect the existence of a double configuration port, consisting of an artificially built embayment in front of the city, harbouring the military vessels and a natural Limanu Valley which was the shelter of the commercial port. Such complex harbour structures were frequent during the Greek and especially Roman Period, particularly at river mouths like it was the case of Portus, Rome's port (Keay et al, 2005) or Forum Iulii (Frejus) (Gébara and Morhange, 2011). However, subsequent archaeological surveys undertaken in the '90s within the city's walls interpreted the previously reported submerged findings as habitation area, not port structures (Alexandru et al., 2009). Yet, recent bath- 
ymetric surveys intercepted a dyke like feature in the proximity of the southern dyke of modern Mangalia Port, while most of the submerged structures reported by Cosma (1973) and Scarlat (1976) are reported as lost during dredging activities undertaken for the modern port construction.

The planview shoreline inspection on cartographic documents between 1926 and 2002 reveals the existence of a sandy barrier at the mouth of the Limanu Valley in quasi-natural conditions (1926) which was further breached at its northern tip which
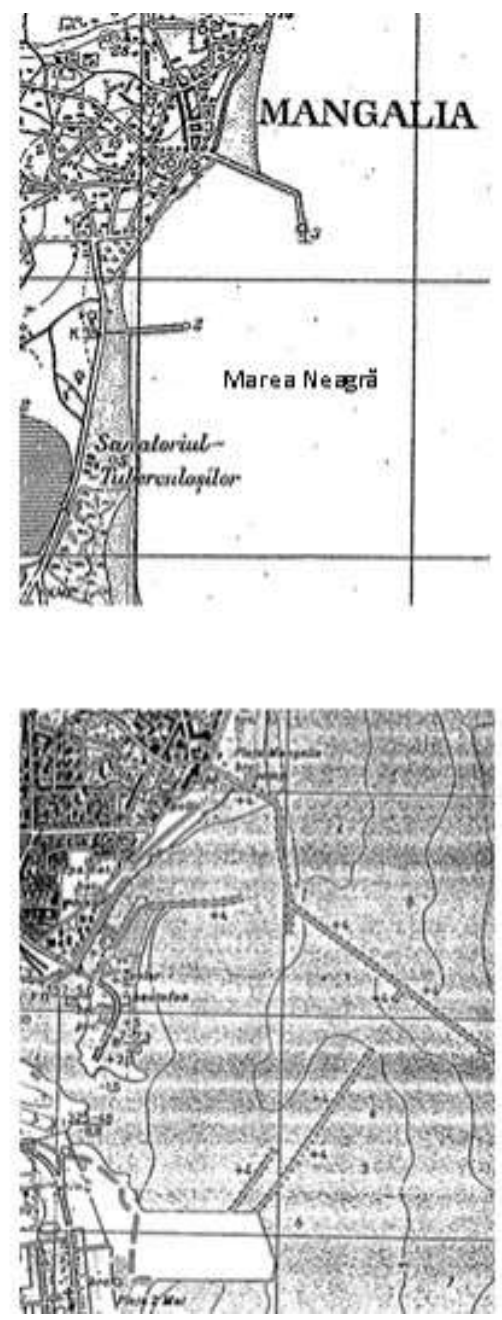

Figure 5 Mangalia (1926-2002). Cartographic documents showing Mangalia shoreline configuration at different times: 1926, 1960, 1979 and 2002 (after Constantinescu, 2012)

\section{Discussions and Conclusions}

A general pattern of morphological configuration could be identified as preferred setting for ancient Greeks to establish their colonies is represented by the presence of a river mouth lying in the proximity was the narrowest to permit the connection between the Limanu or Mangalia Lake with the sea. Its functioning was preserved by the construction of the northward dyke of the port (1960) which otherwise contributed to the sediment depletion and barrier destruction. The barrier was removed by 1979 once with the final configuration of the Mangalia Port (Fig. 5). A remnant of the former barrier persists today as the island in the NE part of the Limanu Lake entrance, where the present-day fishery is emplaced.
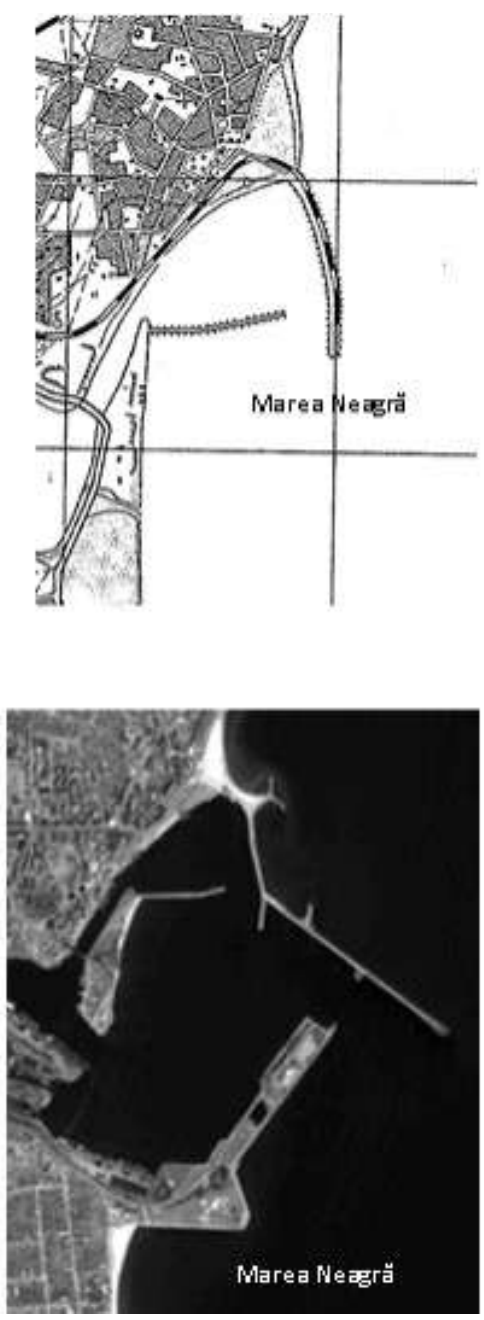

of promontories or rocky heads directly into the sea or into a lake or lagoon. The promontories were particularly set as the fortified siege of political, cultural and administrative part of the city which encompassed the public buildings and the harboring structures, while the neighboring mainland was 
occupied by the residential quartiers. However, if taking into account the natural conditions of sand supply at the time of the Greek colonies foundation and the bidirectional character of wind and waves regime along the Danube delta coast (i.e. 59\% winds coming from the $\mathrm{N}$ vs. $41 \%$ from the south, but due to wind speed and storm asymmetry to the North, the N/S ratio of the sediment longshore transport become as large as $2.53 \mathrm{cf}$. Vespremeanu-Stroe, 2004) it is unlikely that solely the natural shoreline configuration was exploited for harboring vessels. Great variability of the nearshore bathymetry and of the submerged nearshore bars is likely to have affected the navigability along the deltaic coast in natural conditions, therefore artificial harbor structures might have been emplaced in case of Histria. At places with comparatively less sediment input such in the case of Orgame, Tomis and Kallatis the reversing winds and waves might have been imposing an unbalanced marine energy affecting the navigability conditions which required the emplacement of harbors at relatively more sheltered locations that might be found at the southern part of the headlands or promontories. Otherwise, examples from other ancient Greek sites show that the port could have had also a remote position at several $\mathrm{km}$ from the city as is the case of Pergamum's Elaia harbor situated $26 \mathrm{~km}$ away from the city (Seelinger et al., 2014) or even Tomis which some scholars consider as Histrian emporia or harbor (cf. Memnon cited by Andrews, S., 2010).

All the colonies suffered from destructive events at different times caused either by inter-colonial wars, invasions, incendiaries such were those documented for the $3^{\text {rd }} \mathrm{C}$. BC to which were added natural events such as earthquakes or natural siltation and coastline progradation. A combination of the latest natural events should have played an important role in the decline of Histria and Orgame cities which probably generated the collapse of various parts of the rocky limestone/green schist fundament across fault lines such as those intercepted on ERT profiles or investigated and reported in previous works: C-ridge formed at the contact between the old and the young ridge sets of Saele beach ridge plain (Preoteasa et al., 2013) at Histria or visible on the maps at Orgame in the northern part of Doloșman Cape.

The drowned parts of Tomis and Kallatis with large sectors of built structures currently laying under seawater is the result of the marine erosion amplified by karstic and tectonic processes. Intense subsidence processes have been reported by the geophysical and geodynamic studies of the Romanian earth crust which yields the greatest subsidence rate in Dobrudja, reaching up to $-3 \mathrm{~mm} / \mathrm{yr}$ along the coastal strip (Dumitriu, 2012; Rădulescu et al., 2016).

\section{Acknowledgements}

This study was funded from UEFISCDI PNII-RU-TE 110/2018 and partly from 15PFE/2018. I would like to express my gratitude to Prof. Dr. Maria Rădoane for encouraging the writing of this paper and for critical review of the manuscript and to Fredi (Alfred Vespremeanu-Stroe) for useful discussions and review of the earlier draft version. Thanks to Florin Zăinescu and Laurenţiu Tuţuianu who kindly helped with the preparation of the figures for this paper, and to all the friends and colleagues I have worked with in our geoarchaeological projects in the Danube delta: Hanganu Diana, Laurențiu Țuțuianu, Iulian Bârzescu, Rotaru Sabin, Florin Tătui, Marius Pârvan, Alin Păroiu, Liliana Croitoru, Anca Dan and Liviu Iancu. Ştefan Constantinescu and Mihaela Dobre are thanked for providing some of the bibliographical references. The outline of the paper was set during the long walks with Goji who provided the time and inspiration!

\section{References}

Alexandru N, Constantin R, Ionescu M. 2009. Aspecte topografice ale cetăţii Kallatis în epoca romano-bizantină. Pontica, 37-38: 419-438.

Alexandrescu P. 2001. Noi cercetări și ipoteze cu privire la topografia şi urbanismul Histriei. Pontica, 33-34: 179198.

Andrews S. 2010. Greek cities on the western coast of the Black Sea: Orgame, Histria, Tomis, and Kallatis ( $7^{\text {th }}$ to $1^{\text {st }}$ century BCE). PhD thesis, Iowa State University, Digital repository, 206p.

Anthony DW. 2010. The rise and fall of old Europe. In: Anthony DW, Chi J. (eds.): The lost world of Old Eu- 
rope. The Danube Valley, 5000-3500 BC. New York: Institute for the Study of the Ancient World: 28-57.

Avram A, Hind J, Tsetskhladze G. 2004. The Black Sea Area. In: Hansen $\mathrm{MH}$ and Nielsen $\mathrm{TH}$ (eds.): An inventory of Archaic and Classical poleis. Oxford Press, 924-973.

Bailey D. 2000. Balkan Prehistory: exclusion, incorporation and identity. London and New York: Routledge.

Balabanov I. 2002. Holocene sea-level changes in the Black Sea. In: Yanko-Hombach V, Golbert AS, Panin N, Dolukanov PM (eds.): The Black Sea Flood Question: Changes in Coastline, Climate and Human Settlement. Springer, Dordrecht, 711-730.

Bolikhovskaya NS, Porotov AV, Richards K, Kaitamba MD, Faustov SS, Korotaev VN. 2018. Detailed reconstructions of Holocene climate and environmental changes in the Taman (Kuban River delta region) and their correlations with rapid sea-level fluctuations of the Black Sea. Quaternary International, 465: 22-36.

Bony G, Marriner N, Morhange Ch, Kaniewski D, Perincek D. 2012. A high-energy deposit in the Byzantine harbour of Yenikapi, Istanbul (Turkey). Quaternary International, 266: 117-130.

Bony G, Morhange C, Marriner N, Baralis A, Kaniewski D, Rossignol I, Lungu V. 2015. History and influence of the Danube Delta lobes on the evolution of the ancient harbour of Orgame (Dobrogea, Romania). Journal of Archaeological Science, 61:186-203.

Bounegru O. 2002. Comerț și navigatori la Pontul stîng și Dunărea de Jos (sec. I-III.p.Chr). Casa editorială Demiurg, 284p.

Bounegru O. 2003. Portul Histriei în Antichitate în: Economie și societate în spațiul ponto-egean sec. II AC-III PC. Casa Editorială Demiurg, Iași (2003): 34.

Brătescu C. 1944. Oscilaţii de nivel ale apelor şi bazinului Mării Negre. Bul. Soc. Reg. de Geografie, IXL: 66-107.

Buzoianu L, Bărbulescu M. 2011. Materiale arheologice elenistice recent descoperite in teritoriul Callatian. Peuce, IX: 459-468.

Brückner $\mathrm{H}$, Kelterbaum D, Marunchak O, Porotov A, Vött A. 2010. The Holocene sea level story since 7500 BP lessons from the Eastern Mediterranean, the Black and the Azov Seas. Quaternary International, 225 (2): 16-179.

Capotă A. 1980. Studiu geologic, hidrologic şi chimic privind apele mezotermale sulfuroase din zona Mangalia de Nord, Bucureşti.

Chepalyga A. 1984. Inlands sea basins. In: Velichko AA, Wright HE, Barnosky CW (eds.): Late Quaternary Environments of the Soviet Union. University of Minnesota Press, Minneapolis, 237-240.

Constantinescu Șt. 2012. Analiza geomorfologică a ţărmului cu faleză între Cap Midia şi Vama Veche. Editura Universitară, 182p. (in Romanian)
Constantinescu Șt, Giosan L. 2017. Marginal deltaic coasts in transition: from natural to anthropogenic along the southern Romanian cliffed coast. Anthropocene, doi.org/10.1016/j.ancene.2017.08.005.

Dăbâca M. 2012. Instalaţii portuare în cetăţile greco-romane din jurul Pontului Euxin. SCIVA, 63(3-4): 357359.

Dăbâca M.2013. Noi cercetări arheologice în partea de sud a cetăţii Histria. Campaniile 2003-2009. Materiale şi cercetări arheologice, SN IX: 157-188.

Delile H, Abichou A, Gadhoum A, Goiran JP, Pleuger E, Monchambert JY, Wilson A, Fentress E, Quinn J, Ben Jerbania I, Ghozzi F, 2015. The geoarchaeology of Utica, Tunisia: The paleogeography of the Mejerda Delta and hypotheses concerning the location of the ancient harbor. Geoarchaeology, 30(4): 291-306.

Dimitriu RG.2012. Geodynamic and hydro-geological constraints regarding the extension of the prospective archaeo-cultural area within the northern Romanian coastal zone. Quaternary International, 261: 32-42.

Fedorov PV, Skira IA.1957. Epoca actuală în istoria geologică a Mării Negre. Analele Rom. Sov. Seria Geol. Geogr., 3.

Filipova-Marinova M, Pavlov D, Giosan L. 2016. Multiproxy records of Holocene palaeoenvironmental changes in the Varna Lake area, western Black Sea coast. Quaternary International, 401: 99-108.

Flaux C, El-Assal M, Shaalan C, Marriner N, Morhange C, Torab M, Goiran JP, Empereur JY. 2017b. Geoarchaeology of Portus Mareoticus: Ancient Alexandria's lake harbour (Nile Delta, Egypt). Journal of Archaeological Science: Reports, 13: 669-681.

Florescu R. 2001. Des tremblements de terre et des invasions en Schythie Mineure pendant l'antiquite et l'antiquite tardive. Pontica, 33-34: 451-457.

Halcrow 2011. Iterim Report of the Romanian coastal zone. Administrația Națională Apele Române.

Fouache E, Kelterbaum D, Brückner $H$, Lericolais $G$, Porotov A, Dikarev V. 2012. The Late-Holocene evolution of the Black Sea: a critical review on the so called Phanagorian regression. Quaternary International, 266: 162-164.

Gébara C, Morhange C. 2011. Fréjus (Forum Iulii): le port antique/the ancient harbour. Journal of Roman Archaeology, supplement series, 77, Oxford.

Giaime M, Avnaim-Katav S, Morhange Ch, Marriner N, Rostek F, Porotov AV, Baralis A, Kaniewski D, Brückner H, Kelterbaum D. 2016. Evolution of Taman Peninsula's ancient Bosphorus channels, south-west Russia, Deltaic progradation and Greek colonization. Journal of Archaeological Science: Reports, 5: 327-335. 
Hanganu D. 2012. Histria - studiu de geoarheologie. Unpublished PhD thesis, Bucharest University. (in Romanian).

Kelterbaum D, Brückner $H$, Porotov A, Schlotzhauer U, Zhuravlev D. 2011. Geoarchaeology of Taman Peninsula (SW Russia): the example of the ancient Greek settlement of Golubitskaya 2. Die Erde, 142: 235-258.

Keay S, Millett M, Paroli L, Strutt K. 2005. Portus: an Archaeological Survey of the Port of Imperial Rome. British School at Rome.

Laermans H, May SM, Kelterbaum D, Kirkitadze G, Opitz S, Navrozashvili L, Elashvili M, Brückner H. 2019. Coastal lowlands and floodplain evolution along the lower reaches of the Supsa River (western Georgia). Quaternary Science Journal, 68: 119-139.

Lazăr C. 2012. The catalogue of the Neolithic and Eneolithic funerary findings from Romania. Târgovişte, Cetatea de Scaun Publishing Press.

Marriner N, Morhange Ch, Carayon N. 2008. Ancient Tyre and its harbours: 5000 years of human-environment interactions. Journal of Archaeological Sciences, 35: 1281-1310.

Panin N, Popescu I. 2002. The northwestern Black Sea: climatic and sea-level changes in the Late Quaternary, In: Yanko-Hombach V, Golbert AS, Panin N, Dolukanov PM. (eds.): The Black Sea Flood Question: Changes in Coastline, Climate and Human Settlement. Springer, Dordrecht, 387-404.

Popescu N, Ielenicz M. 2003. Relieful Podişului Dobrogei caracteristici şi evoluţie, Analele Universităţii Bucureşti: 5-58.

Preoteasa L, Vespremeanu-Stroe A, Hanganu D, Katona O,Timar-Gabor A. 2013. Coastal changes from open coast to present lagoon system in Histria region (Danube delta). In: Conley DC, Masselink G, Russell PE, O'Hare TJ (eds.): Proceedings $12^{\text {th }}$ International Coastal Symposium (Plymouth, England), Journal of Coastal Research, SI 65: 564-569.

Preoteasa L, Vespremeanu-Stroe A, Panaiotu C, Rotaru S, Tuțuianu L, Sava T, Bîrzescu I, Dimofte D, Sava G, Mirea DA, Ailincăi S. 2019. Neolithic to modern period paleogeographic transformations in southern Danube Delta and their impact on human settlements from Enisala-Babadag region. Quaternary International, 504: 139-152.
Scorpan C. 1970. Ancore antice descoperite pe coastele submarine ale Kallatisului şi unele probleme ale navigaţiei în Pontul Stâng. SCIV, 21: 639-647.

Scarlat C. 1973. Portul antic Kallatis. Cercetări de arheologie submarină. $A M N, 10$ : 529-540.

Seelinger M, Brill D, Feuser S, Bartz M, Kelterbaum D, Vött A, Klein Ch, Pirson F, Bruckner H. 2014. The purpose and age of underwater walls in the Bay of Elaia of Western Turkey: a multidisciplinary approach. Geoarchaeology: An international Journal, 29: 138-155.

Summerer L. 2007. Greeks and natives on the Southern Black Sea coast in antiquity. In: St. Michel (Hrsg.): The Black Sea: Past, Present and Future, Proceedings of the inter-disciplinary conference in Istanbul, 14-16 October, London, 27-36.

Ştefan AIS. 1974. Cercetări aerofotografice privind topografia urbană a Histriei, I. Epoca romană (sec I-II e.n), RMM-MIA 2.

Rădoi A. 1986. Probleme de Geografie, III.

Rădulescu F, Mocanu V, Nacu V, Diaconescu C. 2016. Study of recent crustal movements in Romania: a review. Journal of Geodynamics, 22 (1-2): 33-50.

Rădulescu A. 1966. Monumente romano-bizantine din sectorul de vest al Cetăţii Tomisului. Constanța, 5-84.

Rădulescu A, Scorpan C. 1971. Rezultate preliminare ale săpăturilor arheologice din Tomis, Parcul Catedralei. Pontica, 8: 9-54.

Vâlsan G. 1935. Sur une platforme littorale en Roumanie. Bul. Soc. Geogr., LIV: 23-31.

Vespremeanu-Stroe A. 2004. Transportul de sedimente în lungul țărmului și regimul valurilor pe coasta Deltei Dunării. Studii și cercetări de oceanografie costieră, 1.

Vespremeanu-Stroe A, Preoteasa L, Hanganu D, Brown T, Bîrzescu I, Toms P, Timar-Gabor A. 2013. The impact of the Late Holocene coastal changes on the rise and decay of the ancient city of Histria (Southern Danube Delta). Quaternary International, 293: 245-256.

Vespremeanu-Stroe A, Zăinescu F, Preoteasa L, Tătui F, Rotaru S, Morhange Ch, Stoica M, Hanganu J, GaborTimar A Cârdan I. 2017. Holocene evolution of the Danube delta: an integral reconstruction and a revised chronology. Marine Geology, 388: 38-61.

Vulpe R. 1969. Note de istorie tomitană. Pontice, 2: 149-167. 